\title{
Entertaining the community: the evolution of civic ritual and public celebration, 1860-1953
}

\begin{abstract}
:
Civic ritual and pageantry have been mainstays of urban culture since the Middle Ages, but it has been suggested that they entered a period of decline from the 1870s onwards. This article suggests that instead, local authorities reformed and revised their use of civic ceremony, celebration and commemoration, in order to keep pace with contemporary culture and to maintain public interest. The towns of Darlington and Middlesbrough are considered to highlight the use of recreational and sensory-rich ritual in the urban setting. It is suggested that historians should therefore adopt a broader methodology and broaden their definition of what constituted civic ritual in the twentieth century.
\end{abstract}

For centuries, urban communities have used ritual and ceremony to collectively mark specific moments in time deemed worthy of celebration and commemoration. ${ }^{1}$ Whether to forge communal bonds, acknowledge shared identity, honour an individual or mark a specific development in local life, civic ritual has proven an effective way of physically expressing ideas. In relation to nineteenth-century Britain, as will be discussed, such occasions of civic ritual have often been rightly identified by historians as used to demonstrate power and convey hierarchical structures to wider urban communities. However, towards the end of the century, civic ritual underwent a gradual process of change which democratized ceremonial and celebratory events, through the embracement of recreation and public festivity.

This article focuses on two case studies, relating to the towns of Darlington or Middlesbrough, in north-eastern England. The staging of civic ritual in these locations in the period under discussion epitomised the manner in which it was transformed. For Middlesbrough, the successful incorporation of communal entertainment as a central component of urban ceremonial events ensured that such occasions were publicly relevant for longer than current historiography reflects. However, for Darlington, less effective management reduced the public appreciation for civic ritual.

\footnotetext{
${ }^{1}$ My thanks go to Tom Hulme for his thoughts on an early draft of this article, along with Shane Ewen and the anonymous reviewers for their extremely helpful guidance.
} 
While Darlington has existed in some fashion since the eleventh century, Middlesbrough was developed, in 1830, as a direct result of industrialisation. However, neither received municipal charters of incorporation until 1853 (Middlesbrough) and 1867 (Darlington), therefore lacked many of the trappings of municipal pageantry associated with civic ritual until the mid-century. Additionally, whereas an established middle-class culture has been identified by many historians as being an integral part of nineteenth-century civic ritual, ${ }^{2}$ a smaller midde-class population in the two towns reduced the influence of such a culture. This was paritcularly true of Middlesbrough, due to unskilled migration to the town. ${ }^{3}$ The town was governed by a core group of industrialists, who were later replaced by the 'shopocracy', key retail magnates. The business interests of these two groups encouraged an outward-looking perspective in terms of place promotion. ${ }^{4}$ In contrast, Darlington was dominated by Quaker landowners, financiers and industrialists, the Pease family. They had controlled the Darlington Board of Health, the precursor to the town council, and once incorporation had taken place, four of the first eight Mayors were Peases. ${ }^{5}$ However, their use of civic ceremony remained marginal.

The examples of the two towns are used here to highlight the need for a revised definition of civic ritual, to suit the late-nineteenth and early-twentieth centuries. The definition of civic ritual adopted for the purposes of this study relates to celebratory, commemorative and ceremonial events, taking place in the public arena, or under the direct auspices of the local authority. This definition is intended to be as inclusive as possible, incorporating a wide variety of occasions, to permit an appreciation of the ways civic ritual was reformed. Although visually appealing,

\footnotetext{
2 S. Gunn, The Public Culture of the Victorian Middle-Class: Ritual and Authority in the English Industrial City, 1840-1874 (Manchester, 2000) 163-86.

${ }^{3}$ M. Yasumoto, The Rise of a Victorian Ironopolis: Middlesbrough and Regional Industrialization (Woodbridge, 2011), 63-71.

${ }^{4}$ See T. Warwick, 'Middlesbrough's Steel Magnates: Business, Culture and Participation, 1880-1934', University of Huddersfield Ph.D. thesis, 2015 and R. Lewis, 'The evolution of a political culture: Middlesbrough, 1850-1950', in A.J. Pollard, Middlesbrough: Town and Community 1830-1950 (Stroud, 1996) 103-126. For more on the 'shopocracy', see B.M. Doyle, 'Rehabilitating the retailer: shopkeepers in urban government, 1900-1950', in S. Couperus, C. Smit and D. Jan Wolffram (eds.) In Control of the City: Local Elites and the Dynamics of Urban Politics, 1800-1960 (Leuven, 2007), 41-52.

${ }^{5}$ M. Wilson, 'The Quaker Influence in Darlington in the Nineteenth Century', Teesside Polytechnic MA dissertation, 1985, 91; M.W. Kirby, Men of Business and Politics (London, 1984), 62-3.
} 
"traditional" civic ritual, linked to elite citizens and civic hierarchy rendered the civic majority, particularly the working class, passive observers to a theatrical performance. However, this also encouraged working-class observance, as it was essentially a free form of entertainment. Despite this, it has been argued that the appeal of civic ritual was waning by the $1870 \mathrm{~s}$.

The explanation for this is often linked to changes in the social composition of urban Britain, which reduced the unifying appeal of such occasions, competition from an ever-growing mass leisure industry which reduced the entertainment value of civic pageantry and finally widespread reform of local governance. ${ }^{6}$ However, rather than being a causal factor in the decline of civic ritual, public recreation and entertainment were used by local authorities, including those in Darlington and Middlesbrough, to stage urban ceremonial events in the twentieth century. This was achieved by drawing on the precedent of previous public events in order to assess success and failure of modes of ceremony and commemoration. By approaching event planning through comparison of even seemingly disparate occasions, those responsible were able to take appropriate action regarding what could be repeated, what required adaptation and what needed to be abandoned. Entertainment also became a central theme of civic event planning, transitioning the individual from a passive viewer of rigid Victorian pageantry and ceremony, to an active participant in the event.

\section{Civic ritual: the historiographical and methodological position}

There has been general recognition that 'invention' and remodelling were central to many longestablished traditions incorporating civic ritual. David Cannadine's consideration of the Colchester Oyster Feast acknowledged that the meaning of such events was never static, while identifying the years 1880 to 1914 as a period when civic, national and imperial leaders used ceremonial events as a means of promotion and glorification. ${ }^{7}$ Most tellingly, Cannadine acknowledged that civic ritual was 'the product and embodiment of changing circumstances', while playing a role 'in the

\footnotetext{
${ }^{6}$ See Gunn, Public Culture, 163-86; B. Beaven, Visions of Empire: Patriotism, Popular Culture and the City, 18701939 (Manchester, 2012); J. Garrard, 'The mayoralty since 1835' in A. O’Day (ed.), Government and Institutions in the Post-1832 United Kingdom (Lampeter, 1995) 1-29.

${ }^{7}$ D. Cannadine, 'The transformation of civic ritual in modern Britain: the Colchester Oyster Feast', Past and Present, 95 (1982), 107-30. These years also saw a proliferation of newly-established or 'invented' customs across Europe. See E.J. Hobsbawm, 'Mass-producing traditions: Europe, 1870-1914' in E.J. Hobsbawm and T. Ranger (eds.) The Invention of Tradition (Cambridge, 1993), 263-307.
} 
creation of these contexts and cultural systems. ${ }^{, 8}$ This made its complexity and significance as a historical marker clear, but overlooked the need to approach these events comparatively.

Comparison between different commemorative, ceremonial and celebratory events, as will be demonstrated, is essential in order to interpret the changes to which civic ritual was subject. ${ }^{9}$ This approach identifies the ways in which the social composition of communities altered, while showcasing the relationship between civic ritual and contemporary cultural trends - something that was contemporaneously clear to the planners of civic events. Cannadine and Elizabeth Hammerton's study of Queen Victoria's Diamond Jubilee in Cambridge, for example, demonstrated the necessity to examine the planning stages of the civic celebration in order to critically assess the whole event. ${ }^{10}$ Methodologically, this ensures that analysis of both "production and reception' remains balanced. ${ }^{11}$ Planning records are frequently more informative than postevent reports, as they often highlight rejected or cancelled elements of an occasion, revealing any associated message which the organizers wished to convey - or perhaps more tellingly, avoid.

In recent years, historians have made significant strides to re-evaluate the use of urban ritual and space, particularly concerning the early-to-mid twentieth century. ${ }^{12}$ Specifically, Dion Georgiou's work on carnivals showcased the manner in which entertainment and spectacle could be melded to act as a prism of civic culture. ${ }^{13}$ The work of Mark Freeman, Tom Hulme and Charlotte Wildman has also highlighted municipal government's utilisation of civic ceremony and

\footnotetext{
${ }^{8}$ Cannadine, 'Colchester Oyster Feast'.

${ }^{9}$ D. Handleman, Models and Mirrors: Towards an Anthropology of Public Events (Cambridge, 1990), 7.

${ }^{10}$ D. Cannadine and E. Hammerton, 'Conflict and consensus on a ceremonial occasion: the Diamond Jubilee in Cambridge in 1897', Historical Journal, 24 (1981), 111-46.

${ }^{11}$ P. Mandler, 'The problem with cultural history', Cultural and Social History, 1, (2004), 94-117.

12 Paul O'Leary's consideration of processional culture adopted a chronologically longer and more inclusive methodology, producing significant results. See P. O'Leary, Claiming the Streets: Processions and Urban Culture in South Wales, c. 1830-1880 (Cardiff, 2012). Laura Harrison's study of youth culture in the city of York sheds light on the ritualistic manner in which urban space was utilised outside of the remit of 'official' civic life. See L. Harrison, 'Negotiating the Meanings of Space: Leisure, Courtship and the Young Working Class of York, c.1880-1920', University of Leeds Ph.D. thesis, 2015.

${ }^{13}$ D. Georgiou, “"The drab suburban streets were metamorphosed into a veritable fairyland”: spectacle and festivity in the Ilford Hospital Carnival, 1905-1914,' The London Journal, 39 (2014), 227-48; D. Georgiou, 'Redefining the carnivalesque: the construction of ritual, revelry and spectacle in British leisure practices through the idea and model of 'carnival', 1870-1939', Sport in History, 35 (2015), 335-33.
} 
historical pageants for boosterism and to encourage civic pride in the local population. ${ }^{14}$ This builds on the work of Marie Dickie, who identified similar motivations by political parties in relation to the use of civic ritual in the interwar period. ${ }^{15}$ Clearly then, much work has already been undertaken in relation to civic ritual into the twentieth century. Indeed, all of these studies share commonalities. Yet, while there is growing realisation that urban ritual and ceremony is an important cultural construct, there is still a need to recognise the role of precedent in relation to event planning. It is only by bringing together seemingly disparate urban rituals to extrapolate their shared facets that civic ceremony can truly be understood.

In addition to the need for comparison between events, previous studies have also frequently focused on cities, rather than towns. Simon Gunn's research concerning the use of pageantry and ceremony in nineteenth-century cities suggested that by the 1870s, the staging of city-based civic ritual had gone into decline, in no small part due to the effects of consumerism. ${ }^{16}$ Given the focus of Gunn's work, it is easy to understand why this assessment was made, as the years after 1870 witnessed unprecedented social change, which irrevocably altered the structure of civic culture and governance. ${ }^{17}$ However, Gunn also stated that studies of civic ritual focusing on towns rather than 'larger provincial cities' might not appreciate 'the urban context' and 'anonymity' a city presented, as the larger setting witnessed 'problems of order, authority and identity', which civic ritual attempted to address. ${ }^{18}$ Towns undeniably faced different problems and challenges from those experienced in a larger city or conurbation. Yet, consideration of smaller communities, particularly those with a dominant industrial base, allows a broader understanding of civic

${ }^{14}$ M. Freeman, “'Splendid display; pompous spectacle”: historical pageants in twentieth-century Britain', Social History, 38 (2013), T. Hulme, ““A Nation of Town Criers”: Civic Publicity and Historical Pageantry in Interwar Britain', Urban History (Forthcoming, 2016), 423-455; C. Wildman, 'The "Spectacle" of Interwar Manchester and Liverpool: Urban Fantasies, Consumer Cultures and Gendered Identities', University of Manchester Ph.D thesis, 2007.

${ }^{15}$ M. Dickie, 'Town patriotism in Northampton, 1918-1939: An invented tradition?', Midland History, 17 (1992), 109-117.

${ }^{16}$ S. Gunn, 'Ritual and civic culture in the English industrial city, c.1835-1914', in R.J. Morris and R.H. Trainor (eds.) Urban Governance: Britain and Beyond Since 1750 (Aldershot, 2000) 226-41, 236.

${ }^{17}$ R.P. Dockerill, 'Local Government Reform, Urban Expansion and Identity: Nottingham and Derby, 1945-1968', University of Leicester Ph.D. thesis, 2013, Chapter 2.

${ }^{18}$ Gunn, 'Ritual and civic culture', 227. 
ceremony, celebration and commemoration. Both Gunn and Cannadine acknowledge that civic ritual reached its zenith in the 1880 s through to 1914 in smaller communities. ${ }^{19}$

What has been less acknowledged was the increasing public call to directly participate in occasions utilising urban ceremony, together with the demand for recreation and entertainment at moments when ritual was enacted. As will be shown, in Darlington and Middlesbrough, it was awareness of this, together with changes in the planning process, which enabled the continuation of civic ritual. Crucially, this was a period when the individual had become a consumer of recreation, rather than just a participant. Therefore, urban ceremony was designed to be appealing, in order to maintain public interest at a time when the diversification of the leisure industry was capturing the attention of the public. ${ }^{20}$ Ultimately, this was only challenged by the leisure industry's growth in the inter-war period. ${ }^{21}$ This reveals the importance of viewing the spectator or participant in civic ritual as a consumer, eager for entertainment. ${ }^{22}$ Being present at or participating in such an occasion could, after all, be dependent on something as minor as personal mood and attitude, rather than engagement with the broader themes of an event. ${ }^{23}$ The separation between endorsing ritual with specific meaning and merely viewing it in terms of recreation is, as Émile Durkheim acknowledged, marginal at best. ${ }^{24}$ Consequently, with the entertainment value of traditional civic ritual being challenged by an ever-ebullient leisure industry, the need for local authorities to make increased use of recreation in a ritualistic manner in order to reinforce the appeal of pageantry and ceremony is clear.

\footnotetext{
${ }^{19}$ Ibid., 178.

${ }^{20}$ See H.E. Meller, Leisure and the Changing City, 1870-1914 (London, 1976); P. Bailey, Leisure and Class in Victorian England: Rational Recreation and the Contest for Control, 1830-1885 (London, 1978); H. Cunningham, Leisure in the Industrial Revolution, c. 1780-c. 1880 (London, 1980); W.H.Fraser, The Coming of the Mass Market 1850-1914 (London, 1981); J. Benson, The Rise of Consumer Society in Britain 1880-1980 (Harlow, 1994); and Matthew Hilton, Consumerism in $20^{\text {th }}$ Century Britain (Cambridge, 2003).

${ }^{21}$ Beaven, Visions of Empire.

${ }^{22}$ A. King, 'Acts and monuments: national celebrations in Britain from the Napoleonic to the Great War', in A. O'Day, (ed.) Government and Institutions in the Post-1832 United Kingdom (Lampeter, 1995) 237-68.

${ }^{23}$ M. Archer, Being Human: The Problem of Agency (Cambridge, 2000) 214.

${ }^{24}$ É. Durkheim, The Elementary Forms of Religious Life (1912) (Oxford, 2001) 282-283.
} 


\section{The transition from traditional to recreational civic ritual, 1860-1897}

Soon after municipal incorporation, Middlesbrough Council began to successfully draw upon civic ritual to promulgate an emergent local identity in a population of industrial migrants, while externally promoting the infant industrial powerhouse as a flourishing urban centre. This was achieved through various means between the 1850s and 1880s, including the annual staging of Mayoral Sunday pageantry, regular use of 'urban development ceremonies' (including foundation stone laying and the opening of public buildings), royal visits and the staging in 1881 of a local jubilee to mark the fiftieth anniversary of the town's establishment. ${ }^{25}$ In this sense, the approach taken correlated with the staging of Victorian civic ritual throughout Britain, ${ }^{26}$ thanks to robust municipal leadership, with a solid understanding of the benefits of urban ceremony. In contrast, Darlington's local government consistently failed to understand the potential of civic ritual, largely due to the political dominance of the Pease family. Under their influence, use of urban ceremony in Darlington was decidedly piecemeal. For example, instead of utilising royal visits (and associated national press attention) to showcase urban development, a Pease family member would frequently officiate, if a ceremony was staged at all. When pageantry was utilized, such as for the fiftieth anniversary celebrations of the Stockton-Darlington passenger railway line in 1875, the spotlight was firmly transfixed on the family and their industrial and paternalistic prominence. ${ }^{27}$

The transition to recreational civic ritual and the importance of using the precedent of previous occasions in event planning was not automatic. Instead, there was a transitionary period, with increased municipal awareness that civic ritual was strongly linked to public attitude and taste. For example, the celebration of Middlesbrough's 1881 jubilee included two processions - one for local officials and one for children. ${ }^{28}$ This presented an opportunity for the youth of the town to be linked to its future through the active promotion of citizenship and permitted the participation of a

\footnotetext{
${ }^{25}$ B. Roberts, 'Civic Ritual in Darlington and Middlesbrough in Comparative Perspective, c.1850-1953', Teesside University Ph.D. thesis, 2013.chapters 5-7.

${ }^{26}$ Dickie, 'Town Patriotism', 109-117, V. Fulda, 'Space, Civic Pride, Citizenship and Identity in 1890s Portsmouth', University of Portsmouth Ph.D. thesis, 2006; R. Rodger, 'The common good and civic promotion: Edinburgh 18601914,' in R. Colls and R. Rodger (eds.) Cities and Ideas: Civil Society and Urban Governance in Britain 1800-2000 (Aldershot, 2004), 144-77.

${ }^{27}$ Roberts, 'Civic Ritual', 168-87.

${ }^{28}$ North Eastern Daily Gazette (NEDG), 11 Jul. 1881.
} 
significant portion of the population. Additionally, several of the associated ceremonial events were staged in the local park, increasing spectator opportunities. ${ }^{29}$ The public mood was indicative of general festivity. A report by The Times described Middlesbrough as 'en-fete', with the townscape transformed under a sea of decorations. ${ }^{30}$ In total, an estimated 120,000 assembled for the occasion - well over double the town's population - emphasising the extent to which this was also a major tourist event. ${ }^{31}$ There was also a degree of surprise regarding the occasion's success. As one local newspaper acknowledged, Middlesbrough was still largely unfamiliar with largescale pageantry and therefore 'everything had to be improvised. ${ }^{32}$ Clearly, the lack of a suitable precedent, which would later become so vital to the adaptation of civic ritual, was viewed as a potential hindrance.

Efforts to be more inclusive in the staging of civic ritual were likely driven by a desire to avoid the singularity of Darlington's 1875 railway (Pease) jubilee. Instead, Middlesbrough Council's staging of urban ceremony focused on the promotion and celebration of the wider community. Two years later, when the laying of the foundation stone of Middlesbrough's new town hall was planned, local officials decided against incorporating masonic ritual into the occasion, as had been done 23 years earlier, for the laying of the North Riding Infirmary's foundation stone. ${ }^{33}$ On that occasion, such a move had been a prudent measure, as the young town did not yet possess a strong municipal identity. Yet by 1883, a shift in public attitudes in the town regarding freemasonry left councillors feeling that local people 'no longer approved' of masonic ritual. ${ }^{34}$

${ }^{29}$ H.G. Reid, Middlesbrough and its Jubilee (Middlesbrough, 1881), 228-73.

${ }^{30}$ TT, 5 Oct. 1881.

${ }^{31}$ Ibid., 230. This was linked the development of 'tourism-in-time,' where major events acted as catalysts for heritage promotion, juxtaposed with contemporary prosperity. See P. Usherwood, 'Myths of Northumberland: art, identity and tourism, in R. Colls (ed.) Northumbria; History and Identity 547-2000 (Chichester, 2007), 239-255.

${ }^{32}$ NEDG, 10 October 1881.

${ }^{33}$ Darlington and Stockton Times, 11 Aug. 1860.

${ }^{34}$ Teesside Archives (TA), Proceedings of Middlesbrough Borough Council, 28 Aug. 1883, CB/M/C 1/43. While this was never fully explained, there is evidence of similar hostility in Darlington. Freemasons had been excluded from public participation in the 1875 railway jubilee and several members of the Pease family (perhaps motivated by their Quaker beliefs) spoke openly in opposition to Freemasonry. See The Freemason, 23 Oct. 1875, 30 Dec. 1876 and 6 Jan. 1877. 
Despite apparent awareness that it was important to consider public opinion when planning a ceremonial event, the occasion, witnessed by thousands of spectators, still largely followed the example set by similar occasions in larger cities. ${ }^{35}$ These examples suggest an early effort to adapt the planning of civic events in the 1880s. Yet, an 1887 Whitehall directive that Queen Victoria's Golden Jubilee should be observed in some fashion caused considerable confusion for civic authorities throughout Britain. As no specific recommendations were issued, it was up to individual councils to determine the form of celebration most suitable for their particular community. ${ }^{36}$ The difficulty came with the absence of precedent; the Silver Jubilee of the reign had not been observed and the Golden Jubilee of the Queen's grandfather, George III in 1810, had taken place before widespread urbanisation, making it a poor example. Modes of urban ritual and ceremony that had been popular in the early nineteenth century had given way to the forces of rational recreation and regulations linked to public order. ${ }^{37}$

For the first time, the importance of precedent in event planning became obvious in Darlington and Middlesbrough, with their respective local jubilees assisting in the planning process. In Darlington, a significant advance was made in terms of incorporating the public into the event by including celebrations for approximately 11,000 local residents, with focus on schoolchildren and the elderly. ${ }^{38}$ However in Middlesbrough, initial unwillingness to engage with a royal event on the part of the Liberal-controlled town council complicated the planning process. ${ }^{39}$ After much internal wrangling, the town's observance of the jubilee was more representative of traditional civic ritual than continued adaptation. A large-scale procession was staged, terminating in the local park, where a public thanksgiving service was held, along with some public entertainments. The principal focus, however, remained on the glorification of the monarch, simultaneously promoting and celebrating the primacy of the local authority as the immediate representatives of authority -

\footnotetext{
${ }^{35}$ NEDG, 24 Oct. 1883.

${ }^{36}$ King, 'Acts and monuments'.

37 See R.W. Malcolmson, Popular Recreations in English Society, 1700-1850 (London, 1973), 118-57; J.M. Golby and A.W. Purdue, The Civilisation of the Crowd: Popular Culture in England, 1750-1900 (Stroud, 1999), 17-62; E. Griffin, England's Revelry: A History of Popular Sports and Pastimes, 1660-1830 (Oxford, 2005) 56-113.

${ }^{38}$ Darlington Centre for Local Studies (DCLS), Programme of Darlington Celebrations, 1887, u418h/28173.

${ }^{39}$ Northern Echo (NE), 12 Jan. 1887; NEDG, 24 Jan. and 23 Mar. 1887.
} 
despite their political position. ${ }^{40}$ On the whole, 1887 functioned as an important learning curve for municipal councils regarding the future shape of public ceremony, celebration and commemoration.

While the precedent of local jubilees had served both towns well, the Queen's Golden Jubilee celebrations established a structure which could be rolled out (with timely adaptation) for future events. While the transition to recreational civic ritual was not yet complete, occasions which excluded the public were becoming increasingly rare. In 1889, when Middlesbrough welcomed the Prince and Princess of Wales to open a new town hall, there was public anger that local councillors were allocated 20 tickets for their friends and family, reducing the number available for public consumption. ${ }^{41}$ The availability of any public tickets was a considerable development concerning access to moments of high ceremony, but more crucial was the reaction of the public. In a major departure from the framework of civic ritual for the majority of the Victorian period, widespread involvement in such occasions was becoming automatically expected.

The provincial response to Queen Victoria's Diamond Jubilee of 1897 was the catalyst for broader change. The precedent of the 1887 celebrations was used in both towns and accompanied a broader acceptance that society could no longer be represented by modes of civic ritual which, at best, represented a simpler time and at worst, came from a pre-industrial age, unreflective of contemporary reality. There would no longer be any question whether the public would be included in such occasions; the difficulty came from the manner in which involvement would be guaranteed. Ceremonial roles, central to traditional civic ritual, could only be allocated to so many. Even a large, inclusive procession could only include a small percentage of the local community without becoming unmanageable. The embracement of forms of entertainment at moments of widespread celebration was therefore largely unavoidable and continued the pattern observed in communities such as Darlington in 1887. Consequently, 1897 can justifiably be seen as inaugurating a new definition of civic ritual, firmly linked to recreation.

\footnotetext{
${ }^{40} N E$, 25 Jun. 1887. For more on the relationship between Liberalism and support for the monarchy see J. Parry, 'Whig Monarchy, Whig nation: Crown, politics and representativeness, 1800-2000,' in A. Olechnowicz (ed.), The Monarchy and the British Nation 1780 to the Present (Cambridge, 2007), 47-75.

${ }^{41} N E D G, 17$ Jan. 1889.
} 


\section{Entertainment as public ritual, 1897-1914}

The 1897 jubilee celebrations were approached with revived confidence by municipal planners. With the precedent of earlier celebrations in place, local authorities became increasingly inventive with the content of their event programmes, paving the way for reconsideration of what constituted civic ritual. Gone were overt demonstrations of local hierarchy as a singular conveyance of sentiment. Instead, municipal processions operated alongside more democratic and simultaneously frivolous forms of public ceremony. Under the auspices of Middlesbrough Mayor Samuel Sadler, three civic processions were planned, alongside an unprecedented amount of variety entertainments, bands, games, contests, sports and a balloon to carry people ' $100 \mathrm{ft}$ into the air'. Proceedings were concluded by a 'display of fireworks on a magnificent scale'. ${ }^{42}$ Personally funding the celebrations, Sadler intended that the day be the 'maddest merriest day of all of the glad year... a great al fresco fête' to include 'old and young, rich and poor, indeed, everybody of every class,' to celebrate 'in such a way as had never been [done so] in Middlesbrough before and probably never would again. ${ }^{43}$

Personality politics played a role in defining how individual local authorities approached such events. Whereas Middlesbrough had been governed by a Liberal mayor in 1887, Sadler's Conservatism made him more naturally attuned to overt demonstrations of patriotism. His apparent munificence correlated with a national pattern of local elites linking civic identities to "national and imperial narratives'. ${ }^{44}$ Yet the decision also afforded Sadler a degree of political capital. He was a career politician and in 1878, had been accused of 'buying votes' through public generosity. ${ }^{45}$ Local commemorations allowed municipal leaders to demonstrate the 'quality of their leadership ${ }^{46}$ through their generosity (of spirit as well as money) and also the extent to which they 'spoke' for the people. This could be interpreted as a revised version of power demonstration,

\footnotetext{
${ }^{42}$ TA, Diamond Jubilee of Queen Victoria, Official Programme of Celebrations, U/PAT 3/2.

${ }^{43}$ NEDG, 13 April 1897.

${ }^{44}$ Beaven, Visions of Empire, 37. Sadler was also a Freemason, increasing his familiarity with ceremony. For more on the link between local politicians and Freemasonry, see D.M. Lopez and J.K. Walton, 'Freemasonary and civic identity: municipal politics, business and the rise of Blackpool from the 1850s to the First World War,' Manchester Region History Review, 21 (2010), 45-68.

${ }^{45} \mathrm{~J}$. Turner, 'The frontier revisited: thrift and fellowship in the new industrial town, c.1830-1914' in Middlesbrough: Town and Community, 81-102, 95.

${ }^{46} \mathrm{King}$, Acts and Monuments, 239.
} 
through recreational civic ritual rather than traditional urban ritual. If Sadler's munificence was part of a deliberate strategy, it worked; three years later, he was elected as the town's Member of Parliament. Despite this, the provision of recreational festivity was indicative of a change of approach in relation to civic ritual.

The three Middlesbrough processions were a case in point. A civic parade, demonstrating the perceived hierarchy of local authority, was combined with local military personnel, symbolising the relationship between local government and the broader nation. This followed the unusual combination of twenty thousand children and several hundred cyclists and preceded a 'fancy and historic parade. ${ }^{47}$ The difference from the 1887 jubilee was striking; while some components of traditional civic celebrations were maintained (the civic procession and a service of thanksgiving), frivolity had become primary. Hailing the day as a complete success, the local press, demonstrating unashamed partiality, proclaimed the celebrations to be first after London in the 'fullness and variety of the popular rejoicings' ${ }^{48}$ While the scale of the Middlesbrough programme was noteworthy, the town actually followed a pattern witnessed throughout the country. ${ }^{49}$ In 1887 , celebrations in Darlington only catered for the very young and old. By 1897, entertainment was provided for the entire population, with a week-long programme to reflect changing working patterns. ${ }^{50}$ The core of the occasion still celebrated the longevity of the monarch, but the process of doing so was undoubtedly driven by recreation, placing the public at the heart of festivities. Municipal politicians essentially became merely figureheads or characters in a theatrical production designed to entertain, in the guise of a dignified commemoration.

The 1897 jubilee programme was repeated in both towns for the coronations of Edward VII in 1902 and George V in 1911, attesting to the success of the model which had been adopted. This use of precedent also minimised complications linked to limited event-planning experience as a result of changes in local government, or the job roles of municipal personnel. Where adaptation was made, it kept pace with the ebb and flow of popular culture in the particular locale, further demonstrating the link between urban ritual and recreation. For instance, in 1911, Middlesbrough Council arranged a 'grand water carnival' on the Albert Park lake, to include rowing, swimming

\footnotetext{
${ }^{47}$ NEDG, 27 Apr. 1897.

${ }^{48}$ NEDG, 21 Jun. 1897.

${ }^{49}$ Manchester Guardian (MG), 23 Jun. 1897; The Times, 24 Jun 1897.

${ }^{50} \mathrm{NE}, 4$ Jun. 1897.
} 
and other aquatic sports. This intersected with the general popularity of water-based sports in the area, ${ }^{51}$ particularly connected with local swimmer Jack Hatfield, who, a year later, won two silvers and a bronze at the Stockholm Olympic Games. Access to official swimming facilities and membership of local clubs could be costly, ${ }^{52}$ making occasions of free participation extremely beneficial. Provincial royal event commemoration was therefore driven by public mood to maintain local interest. This raises the question of whether communities would have been as willing to participate in a royal event if it had not provided entertainment. Ongoing political and industrial unrest made the future of monarchy and engagement with royal celebrations by no means certain in the early twentieth century. ${ }^{53}$

The period was testing for many long-established modes of urban custom and ceremony. The urban development ceremony, for example, was increasingly superfluous. Newspaper reports provided all necessary information to promote a new building or facility, reducing the need for a ceremony, which the majority of the general public would only passively witness. ${ }^{54}$ In response, local authorities attempted to make public opening ceremonies more inventive - with mixed results. The 1889 opening of Darlington Municipal Baths saw the Mayor drop coins into the pool, which leading members of the local diving club retrieved, much to the scorn of the local press. ${ }^{55}$ 1900 saw the opening of a children's unit at Middlesbrough's North Riding Infirmary, marked by the Mayor and Mayoress carrying children through the main doors onto the ward. Following the occasion, the North Eastern Daily Gazette heavily criticized its absurdity, while recognising that elaborate civic ceremony was becoming rare. ${ }^{56}$ The most irrational development ceremony came in 1921, when the inauguration of a new bus service between Middlesbrough and nearby Seaton

\footnotetext{
${ }^{51}$ M.J. Huggins, 'Leisure and sport in Middlesbrough, 1840-1914,' in Middlesbrough: Town and Community, 127152; C. Budd, 'The Growth of an Urban Sporting Culture - Middlesbrough, c. 1870-1914', De Montfort University Ph.D. thesis, 2012, ch. 4.

${ }^{52}$ Budd, 249-50.

${ }^{53}$ Olechnowicz, 'A jealous hatred: royal popularity and social inequality' in Monarchy and the British Nation, 280314.

${ }^{54}$ Roberts, 'Civic ritual', 241-2.

${ }^{55}$ NEDG, 8 Jun. 1899.

${ }^{56}$ Ibid., 18 Jul. 1900.
} 
Carew saw members of both councils board buses to meet halfway for a picnic. ${ }^{57}$ Clearly, this was intended to serve as a symbolic act. However, the event attracted no public interest, as it took place on an empty road halfway between the two towns and was not reported by the local press.

When pageantry was still utilized for opening ceremonies, it was linked to individual political figures with a taste for spectacle. In 1901, under the direction of ostentation-loving Mayor Samuel Sadler, the opening ceremony of Victoria Square gardens was undertaken with high decoration, public entertainments, and concerts. ${ }^{58}$ Similarly, the opening of the town's Dorman Memorial Museum in 1904 was marked with a ritualized handing-over of the deeds. ${ }^{59}$ Both events were representative of change in relation to urban ceremony. Public interest in Victoria Square was heightened by press reporting, describing the Square's creation and giving statistics of its size and design. In essence, this was a press release - something that became progressively common and also played a significant role in promoting the Dorman Museum's official opening. As the working-class community was now more informed and politically active, reports focused less on civic ritual and more on the positive public benefits of the new building or institution. This acted as a form of advertisement and reduced the importance of ceremonial events. The museum's opening ceremony was, however, enriched by associated sentiment. The building was a memorial to the son of local industrialist and politician Arthur Dorman, who was killed in the South African War. ${ }^{60}$ This fact was extensively reported, adding an emotional and human dimension to the occasion beyond the standard parameters of a traditional urban development ceremony.

The first decade of the twentieth century saw the formal nature of nineteenth-century urban ceremony give way to the more relaxed and participatory nature of twentieth-century civic ritual. Yet commercialized entertainments and popular culture had, by 1914, diluted the entertainment value of traditional civic ritual, making it comparable to a passing novelty. Indeed, in the wake of the First World War, the supremacy of the local authority as the primary organizer of public ritual - recreational or otherwise - was challenged.

\footnotetext{
${ }^{57}$ TA, Middlesbrough Borough Council, Souvenir of the new Bus Service Between Middlesbrough and Seaton Carew, 4 April 1921, TA, CB/M/C 11/1 (20).

${ }^{58}$ Dorman Museum Collection (DMC), Opening of Victoria Square: Official Souvenir, MIDDM:1967.7.2.

${ }^{59}$ DMC, Opening of the Dorman Memorial Museum: Official Souvenir, MIDDM:NN.226P.

${ }^{60}$ Warwick, 208-211.
} 


\section{Street celebration, sensorial civic ritual and public relations}

Following an understandable reduction in civic ceremony during hostilities, the gradual breakdown of the pre-war social hierarchy and reduction of deference had a noticeable effect on public attitudes to celebratory, commemorative and ceremonial events in peace time. The national Peace Day celebrations of June 1919 were intended to blend traditional solemnity with recreational entertainments in a similar manner to earlier royal celebrations. ${ }^{61}$ Appropriate additions were made to the event programme in Middlesbrough, including the unveiling of a tank, as a war trophy, from the National War Savings Committee. ${ }^{62}$ This visibly represented the brutality of warfare alongside the symbolism of victory. Similarly, the personal face of war was personified by the presence of disabled and demobilized and other servicemen in the larger civic procession. ${ }^{63}$ On paper, a suitable balance was struck, with dignified processions and a service of thanksgiving demonstrating tradition and gravity, while variety entertainments ensured the inclusion of (now expected) recreation associated with public event. Yet, in both towns, the civic experience of a national celebration was partially rejected.

For Darlington, where the local authority had a history of demonstrating a lack of dynamism in relation to urban ceremony, there was a growing perception that the public mood was misunderstood. Firstly, a disagreement between the council and the Head Teachers' Committee regarding procession-marshalling duties resulted in a children's parade being cancelled. ${ }^{64}$ It was also announced that the Mayor and three of his predecessors were to receive the Honorary Freedom of the Borough on Peace Day. ${ }^{65}$ At a hastily convened public meeting, it was claimed that the men 'cannot claim to have earned the title, on an occasion which should have been focused on 'old people, the children and the boys from the front.' The following day, the four men publicly declined the honours, with a carefully-worded statement suggesting that 'the greatest reward' was the 'joy' of public service. ${ }^{66}$ Finally, a planned military procession was cancelled after local

\footnotetext{
${ }^{61}$ DCLS, Peace Souvenir and Programme of Festivities, Darlington 1919, Wooler Book 7, 95; TA, Middlesbrough Peace Celebrations: Official Programme and Souvenir of the Celebration and Festivities, CB/M/C 11/1 (24).

62 TA, Proceedings of the Middlesbrough Borough Council, 30 Jun. 1919.

${ }^{63}$ NE, 21 Jul. 1919.

${ }^{64} N E$, 17 July 1919 and $N E D G, 21$ July 1919. A similar disagreement had occurred in 1911. See $N E$, 1 June 1911.

${ }^{65} \mathrm{NE}, 3$ July 1919.

${ }^{66}$ Ibid., 19 July 1919.
} 
servicemen objected to the exclusion of widows and orphans. Instead, a protest event was held in Darlington Market Place, attended by 'thousands of people who were out to enjoy the holiday. ${ }^{67}$ This event in particular represented a clear difference in attitude between the two towns. Middlesbrough Council had, since the 1880s, taken public opinion into account when planning civic ritual. Clearly, a less cautious approach was taken in Darlington, having a negative effect on public engagement.

Yet, in both towns, the municipal Peace Day celebration also faced competition from the new social phenomenon of the 'street party', which the local press described as 'plebeian celebrations in their most original form' ${ }^{68}$ The street party permitted a more individual connection to be made to specific events. This was particularly reflective of the feeling of relief linked to the end of war, which was better expressed in personal surroundings than was possible through the prism of civic or national identity. Street parties appear to have been a natural development following the breakdown of previous societal authority structures. Contemporary press reports, concerning events in London, suggested that these innovative "street teas" were staged by mothers who felt that their children were too young to attend the larger civic or national ceremonies. ${ }^{69}$ However, the basic structure of street celebrations was strikingly similar to pre-industrial rural recreations, celebrations and customs, due to their informality, the subversion of order and their focus on individual social groups, rather than a broader municipal community. ${ }^{70}$ In essence, they rejected the civic experience. The emotional grounding of the street party was also more prominent. Local newspaper reports acknowledged that the streets were more representative of 'the mood of the moment... [as] the accompanying music of the piano and the cheerful voices of the children made the atmosphere ring with the true stimulating echoes of Peace Day. ${ }^{71}$

The successful embracement of recreational civic ritual enabled the continued transmission of notions of civic paternalism and identity, while recognising the growing inclusivity of urban society. However, recreational civic ritual had also been too successful, making clear the essential

\footnotetext{
${ }^{67} N E D G, 21$ July 1919.

${ }^{68} N E D G, 21$ Jul. 1919.

${ }^{69} M G, 27$ August 1919.

${ }^{70}$ For pre-industrial examples, see B. Bushaway, By Rite: Custom, Ceremony and Community in England 1700-1880 (London, 1982), Malcolmson, 52-88 and Griffin, 84-97.

${ }^{71} N E D G, 21$ Jul. 1919.
} 
components of an effective communal gathering in the urban setting, paving the way for the public to create their own. More than anything, it was the individual staging of events which led to the decline of civic ritual. 1930s royal celebrations (the silver jubilee of George V in 1935 and coronation of George VI in 1937) demonstrated the popularity of street-based celebrations, to the rejection of the civic gala. In addition to providing food and drink, sports and games were organised by street-party committees, with local residents undertaking individual fundraising. One Middlesbrough woman, describing her own street's efforts in 1937, explained that she had made hot soup every night to sell, 'men too old to find jobs...help[ed] mothers with their weekly washing or whitewashed doorsteps, while young lads took babies for walks to give their mothers a rest.' 72 Community-wide participation in event planning generated considerable pride, beyond mere participation. In this sense, the entire process of urban ritual, from organisation through to stagemanagement and participation, had been both claimed and reinterpreted by the public.

For the municipal authority's part, this required a degree of readjustment. In 1937, Darlington Council recognised the supremacy of the smaller event by stating that it was 'impressed with individual street festivities in $1935^{\prime}$ and did not want to discourage them. ${ }^{73}$ In response, municipal ritual began to be scaled back. Local residents noted with irritation that processional routes for Mayoral Sunday parades were getting progressively shorter. ${ }^{74}$ This was largely due to the declining public interest in such occasions, though it gave the impression that the local authority was similarly uninterested, which exacerbated the problem. Additionally, the continued expansion of popular leisure provided an endless list of alternatives to occasions utilising civic ritual. ${ }^{75}$ Alongside the prevailing popularity of home-based leisure, commercial entertainments held considerable appeal on celebration days. In particular, radio technology and the cinema were transforming the sensory experience of everyday life, reducing the basic wonder associated with ceremony and ritual. The cinema, for example, was relatively affordable for most, with the camaraderie and entertainment provided being similar in nature to the appeal of civic ritual. ${ }^{76}$

\footnotetext{
${ }^{72}$ NEDG, 8 May 1937.

${ }^{73}$ Durham Record Office, (DRO) Proceedings of Darlington Council, 25 September 1936, Da/A 7/1/6.

${ }^{74} N E, 2$ and 6 Apr. 1936.

75 Beaven, Visions of Empire, 196.

76 B. Beaven, 'Going to the cinema: mass commercial leisure and working-class cultures in 1930s Britain,' in B. Bebber (ed.) Leisure and Cultural Conflict in Twentieth-Century Britain (Manchester, 2012) 63-83.
} 
In an effort to keep pace with technological (and social) innovation, civic ritual, organised by local authorities, again underwent reformation. The recreational theme was continued, with increasing emphasis on modernity, basic entertainment and informality. The one constant of both nineteenth and twentieth-century urban pageantry was visual appeal. Therefore, civic decoration and illumination schemes for such occasions became increasingly grandiose to attract the public back to the civic event. Similarly, technology was embraced; when the Prince of Wales visited Middlesbrough in 1930, a radio transmitter was set up and events were relayed to five different locations around the town, along with dance music to encourage public revelry. ${ }^{77}$ The principal streets were described as 'one dense seething mass of humanity' during the visit, ${ }^{78}$ though this was probably due to interest in the visitor himself, rather than the council's innovations. A similar approach was taken in 1935 and 1937, with jubilee and coronation broadcasts from Buckingham Palace being transmitted live around the urban centre. ${ }^{79}$ Such broadcasts could, of course, be listened to in domestic privacy. However, promoting a civic link to the occasion validated such events as representations of civic and national community, symbolically located at the heart of the urban landscape.

Civic ritual had become sensorial in nature. Municipal traditions and entertainments enriched the overall experience of urban ceremony and ritual by embracing the carnivalesque. They were increasingly-physical events, ensnaring the entire human sensualistic range, in an attempt to accompany, rather than be subsumed by the development of consumerist leisure. Yet public enthusiasm was waning and this blend of recreational and sensorial appeal was merely a tourniquet for civic ritual. Whereas an estimated 100,000 had gathered in Middlesbrough for the 1897 Diamond Jubilee, the 1935 silver jubilee was estimated to have appealed to $30,000 .{ }^{80}$ While some were no doubt simply uninterested in the occasion, the growth of street and private celebrations played a significant role in this clear rejection of recreational civic ritual. The celebration of an individual street (or even house) created an emotive response through familiarity, intimacy and the

\footnotetext{
${ }^{77}$ TA, Souvenir to commemorate the visit of The Prince of Wales, July $2^{\text {nd }}, 1930, \mathrm{CB} / \mathrm{M} / \mathrm{C} 11 / 2$ (27).

${ }^{78}$ NEDG, 1 Jul. 1930.

79 TA, County Borough of Middlesbrough, Coronation of King George VI: Official Souvenir Programme of Celebrations, CB/M/C 11/36.

${ }^{80} \mathrm{NE}, 7$ May 1935.
} 
involvement of personal relationships - all of which were marginalised by larger-scale public events.

Even local charity carnivals occasionally witnessed the staging of street parties ${ }^{81}$ Events which previously were exclusively public were becoming semi-private following appropriation and translation into more personal terms. The degree to which smaller events such as the street party had become the primary manner in which widely-celebrated or commemorated occasions were marked was noticeable on VE Day 1945 in Middlesbrough, when rather than being the central figure in a civic celebration attended by the public, the mayor toured the borough to witness the various street parties. ${ }^{82}$ There is no recorded indication that he was invited to participate in any of these events and similarly, no reports discussing how the public felt about his presence. The tone struck by the press placed this "tour" as almost a sideshow to the central event - the street party.

The reforms of the Atlee government also impacted the staging of civic ritual. The establishment of a welfare state and the National Health Service removed many of the regular ritualistic events from British streets, such as 'Hospital Saturday [or] Sunday' which had been a regular fundraising event in many towns and cities to raise funds for local funds ${ }^{83}$ Similarly, with the abolition of workhouses and centralization of other public services, processional culture was no longer as effective in demonstrating local hierarchies. By 1953, many local authorities outside of the major cities had significantly curtailed their event planning in recognition of how much public enthusiasm had declined. The coronation of that year witnessed no civic procession in Middlesbrough, with the 'official' event programme being spread over the full summer to include pre-existing functions such as local cricket matches and dances. ${ }^{84}$ In Darlington, criticism of the Corporation's planning of civic ceremony for decades continued, with accusations of a lack of imagination. A correspondent to the Northern Echo stated:

Sir, I am overwhelmed with excitement at the report of Darlington's coronation celebrations...We are to have two trees planted and a bit of skating on the old rink... I

\footnotetext{
${ }^{81}$ TA, Middlesbrough Charity Carnival Souvenir Programme, CB/M/C 11/2 (5).

${ }^{82}$ Evening Gazette (EG), 10 May 1945.

${ }^{83}$ S. Cherry, 'Hospital Saturday, workplace collections and issues in late nineteenth-century hospital funding,' Medical History, 44 (2000), 461-88.

${ }^{84}$ TA, County Borough of Middlesbrough, Coronation of Queen Elizabeth II: Official Programme of Celebrations.
} 
am eagerly looking forward to being one of the thousands gathered to witness the planting of the trees. Perhaps a few other ratepayers would offer to help dig the holes. ${ }^{85}$ While clearly some still expected local authorities to provide entertainments, for others, the problem was broader. Disparagement was even levelled at the municipal decoration scheme, which was said to be too chaotic. ${ }^{86}$ Another correspondent suggested that 'this sort of bungling happen[ed] on every occasion and yet no note of reference to past errors' was ever made. ${ }^{87}$ Rather than using the precedent of earlier events to ensure success, over the course of the twentieth century, Darlington Council failed to understand public attitudes concerning ceremonial occasions. Yet even if a more cautious and considered approach had been adopted, such as had been the case in Middlesbrough, civic ritual would still have been challenged.

By 1953, urban ceremonial events faced another rival in the shape of television, allowing the public to bypass the civic sphere of influence completely to engage with national commemorations without leaving their homes. ${ }^{88}$ Essentially, the television-based national event again compartmentalized the individual and returned them to the passive observer of nineteenth-century ritual. The growth in the popularity of television has been frequently linked to the suburbanisation of Britain, creating a contested space in which urban and suburban ideas were intertwined in the domestic setting. ${ }^{89}$ It cannot be denied that engaging with ceremony and pageantry through television created an entirely new sensory experience. Local authorities attempted to compete, by staging their own civic viewings of the coronation, usually in a town hall or other public place. Had this been successful, it would have generated a new mode of civic ritual, which not only embraced modernity but also paved the way for engagement with a national event through the local prism. Unfortunately, these municipal viewings rarely attracted more than a handful of participants. ${ }^{90}$ The primacy of civic ritual - be it traditional, recreational, sensorial or otherwise had passed.

\footnotetext{
${ }^{85}$ NE, 23 May 1953.

${ }^{86}$ NE, 27 May 1953.

${ }^{87}$ Ibid., 27 May 1953

${ }^{88}$ D. Dayan and E. Katz, Media Events: The Live Broadcasting of History (Massachusetts, 1992), 25-53.

${ }^{89}$ See R. Silverstone, Television and Everyday Life London, 1994), 52-77; R. Turnock, Television and Consumer Culture: Britain and the Transformation of Modernity (London, 2007), 107-117.

${ }^{90}$ TA, Proceedings of Middlesbrough Council, 11 Feb. 1952, CB/M/C 1/113; EG and Northern Despatch, 3 Jun. 1953.
} 


\section{Conclusions}

The evidence from Darlington and Middlesbrough highlights the adaptive nature of civic ritual. Undeniably, many of the mainstays of Victorian urban ceremony, celebration and commemoration had either been lost or completely transformed; yet, there were obvious continuities. The civic procession has a legacy in British (particularly English) urban culture, stretching back to the medieval period. ${ }^{91}$ While the central motivations of civic processions shifted between the nineteenth and twentieth centuries, they were largely recognisable. Certainly, processional culture was less-widely employed in the mid-twentieth century, but still also had its uses. The Mayoral Sunday processions continued in Middlesbrough until the late 1970s. Similarly, the town hosted one of northern England's largest annual Corpus Christi processions until the late 1960s. ${ }^{92}$ Remembrance Sunday processions became mainstay of annual civic ritual throughout the twentieth century. ${ }^{93}$

The difference in the late twentieth century was that increasingly, urban processional culture was less the reserve of the municipal authority and more linked to individual groups or communities, continuing a tradition first established in the nineteenth century by friendly societies and trade unions. ${ }^{94}$ Annual processional culture began to be employed to reassert faith, ${ }^{95}$ or to demonstrate gay pride or ethnic diversity. It can be argued that this continued the tradition of the civic community taking control of civic ritual, ironically making the local authority a bystander to the celebration of individual identities within the urban centre, in complete reversal of the Victorian position.

Civic ritual did not, therefore, disappear in the $1950 \mathrm{~s}$, just as it did not start to decline in the 1870s; it merely changed. As has been shown, no mode of urban ceremony can be studied in isolation. The form of one occasion invariably shaped the next, even if the two were seemingly

\footnotetext{
${ }^{91} \mathrm{~N}$. Murphy, 'Receiving royals in later medieval York: civic ceremony and the municipal elite, 1478-1503,' Northern History, 43, 2, (2006), 241-255; T. Hill, Pageantry and Power: A Cultural History of the Early Modern Lord Mayor's Show, 1585-1639 (Manchester, 2010); P. Borsay, “'All the town's a stage': urban ritual and ceremony 1660-1800,' in P. Clark (ed.) The Transformation of English Provincial Towns (London, 1985), 228-58.

${ }^{92}$ Roberts, 'Civic Ritual,' 91.

${ }^{93}$ M. Quinlan, Remembrance (Hertford, 2005), 29-52.

${ }^{94}$ O'Leary, chs. 3-4.

${ }^{95}$ C. Wildman, 'Religious selfhoods and the city in inter-war Manchester', Urban History, 38 (2011), 103-123.
} 
unrelated in purpose and form. Civic ritual underwent periods of profound reformation, reconstitution and redefinition. It became more representational of community, meritocracy, and shared concepts of belonging, group identity and tradition. The embracement of recreation, leisure and sensorial entertainments reconnected local communities with the urban experience, which lay at the heart of all civic ceremony. At the same time, the difference in attitude between the two municipal bodies considered in this article suggests that keeping pace with public opinion was essential. Time and again, Darlington Council misjudged the mood in the town, leading to criticism of its actions in relation to civic ritual. In contrast, Middlesbrough Council's broader awareness of local feeling ensured that its ceremonial events avoided widespread criticism, even if they progressively declined in popularity. Overall, the evidence suggests that successive generations of municipal officials were aware of the importance of adaptation and modernisation, while borrowing from time-honoured urban traditions. This is something that historians have not fully appreciated, which has led to interpretations of 'decline'. Our definition of what constitutes civic ritual therefore needs to be updated.

Undoubtedly, certain ceremonial events could not be reinvented. The urban development ceremony, for instance, would never see a repeat of Victorian extravagance. In the late twentieth and early twenty-first centuries, local engagement with royal occasions was reduced by the simultaneous effects of declining interest, the continued growth of television and municipal costcutting. In contrast with the 100,000-strong crowd of 1897, an estimated 50 people gathered in Middlesbrough's Centre Square, to partake in a 'big jubilee lunch' for Elizabeth II's Diamond Jubilee in $2012 .{ }^{96}$ Yet this was still, undoubtedly, a civic ritual.

Using the approach of this study, a broader assessment of urban life in the late twentieth century may well reveal other adaptations and reformations which strengthened or reinvented public ceremony for a new generation. The vital task for historians is to recognize that civic ritual was (and still is) a fluid part of urban life. Identifying it can be complex due to the ability of those who create it to learn from the precedent of previous events, keep pace with culture and adapt. It is, however, a valuable, analytical concept which gives us insight into not only contemporary reality but also perceptions of urban continuity and change.

${ }^{96} E G$, 4 Jun. 2012. 